\title{
VARIATION IN NUTRIENT LEVELS AND OTHER WATER QUALITY PARAMETERS IN MINOR IRRIGATIONAL TANKS IN THE KURUNEGALA DISTRICT, SRI LANKA, IN RELATION TO PADDY CULTIVATION: ASSESSING SUITABILITY OF TANKS FOR AQUATIC LIFE
}

Thenuwara, T. T. ${ }^{1}$, Wijesinghe, M. R. ${ }^{1}$, De Silva, D. N. ${ }^{1}$ and Wijesekera, R. ${ }^{2}$

${ }^{1}$ Department of Zoology and Environment Sciences, University of Colombo, Colombo 03.

2 Department of Chemistry, University of Colombo, Colombo 03.

DOl: http://doi.org/l0.4038/sljb.v2i2.12

\begin{abstract}
While providing water for irrigation, the reservoirs have been a source of fresh water for the rural communities, and, more recently, they have become the focus for expanding the inland fishery industry. This paper assessed nutrient enrichment in minor seasonal irrigation tanks in the Kurunegala District in relation to different stages in the paddy cultivation cycle. Findings of the study will be useful to determine their compatibility with safe levels for fisheries, among other uses. The study was extended to cover other selected parameters relating to water quality. Surface water from 50 minor tanks were sampled over pre-cultivation, cultivation and postcultivation stages of the paddy cultivation cycle in the Yala $(\mathrm{n}=27)$ and Maha $(\mathrm{n}=23)$ seasons and analyzed for $\mathrm{NO}_{3}-\mathrm{N}, \mathrm{PO}_{4}-\mathrm{P}$, dissolved oxygen, turbidity, conductivity and $\mathrm{pH}$, using standard methods and portable instruments. Results showed considerable spatial variation in nutrients between the 50 tanks and marked temporal variation through the three sampling stages. For $\mathrm{NO}_{3}-\mathrm{N}$, there was a shift in the proportion of tanks containing low and high nutrient levels through the pre-cultivation, cultivation, and post cultivation stages. The mean levels were 0.01$1 \mathrm{mg} \mathrm{l}^{-1}$ during pre-cultivation and post-cultivation and $1.0-5.0 \mathrm{mg} \mathrm{l}^{-1}$ during cultivation, with distinct peaks observed in the Yala and Maha seasons. The variation of $\mathrm{PO}_{4}-\mathrm{P}$ was different, with the majority of the tanks having levels of $1-5 \mathrm{mg} \mathrm{l}^{-1} \mathrm{PO}_{4}-\mathrm{P}$ during all sampling stages, and with no pronounced peaks. Nutrient levels indicate that a majority of the minor tanks become eutrophic during the two cultivation seasons. The other tested parameters also depicted spatial and temporal variation, and water quality indices revealed that the quality of water deteriorates during paddy cultivation. Based on these findings, particularly for nutrients, we conclude that many of the minor tanks become eutrophic during the cultivation season and may not offer optimal conditions for the intended uses, one of them being rearing of fish and shellfish. Mitigation measures must therefore be implemented to reap maximum benefits associated with these minor irrigation tanks.
\end{abstract}

Key words: aquatic life, irrigation tanks, Kurunegala, nutrients, water quality

*Corresponding author: Tel: 0112503399, 0714405277. E-mail: mayuri@sci.cmb.ac.lk

(iD) http://orcid.org/0000-0002-3402-951X 


\section{Introduction}

The dry and intermediate climate zones of Sri Lanka are dotted with irrigational tanks. These tanks, whose primary function is to supply irrigation water for rice cultivation, were originally constructed many centuries back, mostly in the form of cascades (Sakthivadivel et al., 1997; Shinogi, 2001). In a cascade irrigation system, tanks are constructed at different elevations so that a given paddy field receives water from the tank above it, whilst water from the paddy field is drained to the tank below it. A cascade, with its connected series of tanks, falls within a micro-catchment in a landscape with an undulating topography (Madduma Bandara, 1985). This system, with its optimal management of the water resources, would have been ideally suited for paddy cultivation in ancient times when cultivation was not intensive (Shinogi, 2001). Today, the heavy use of fertilizers, Sri Lanka being ranked as one of the countries in the Asian region with exceptionally high rates of fertilizer use (Ekanayake, 2006), leads to the accumulation of nutrients in irrigation tanks (Silva, 2004: Turner \& Rabelais, 2004). Nutrient accumulation is aggravated during the prolonged dry season, which is characteristic of the dry zone, and to a lesser degree of the intermediate zone. During this period, water levels in the tanks recede considerably, with many of the smaller tanks (or minor tanks) turning into mere water holes and hence termed 'seasonal tanks'. Whilst the water quality in large tanks may not be seriously affected, minor tanks at the lower reaches of the cascades, i.e. those supplying water to less than 80 ha of agricultural land (Murray \& Little, 2000), could be expected to undergo seasonal changes. Minor irrigation system (MIS) or village tank has historically been primarily built to fulfil food security needs of rural communities (Siriweera, 2002).

The irrigation tanks scattered across a land that experiences, annually a dry season of several months, also serve as an important source of freshwater for the rural communities. Another function of the tanks which is of growing importance, is that they support many species of fish and shellfish which are a major source of income for those engaged in the inland fishery industry, and are also a primary source of animal protein for the rural people. To promote inland fisheries, government and non-governmental organizations have released annually juvenile stages of fish and shell fish to irrigation tanks. Large scale increases in the stocking on fingerlings and shrimp larvae (over threefold for fingerlings and over tenfold for shrimp larvae) were recorded in the years 2006 - 2013 (NAQDA, 2015). Heavy nutrient levels have been shown to have severe adverse impacts on fish and shrimp (Thakur \& Kwei, 2003; Nguyen-Khoa \& Lorenzen, 2005).

In view of the widespread use of fertilizers for paddy cultivation and the possibility of a high accumulation of nutrients, we carried out an investigation covering a number of minor tanks located in the lower reaches of the cascade system (and which are also by nature smaller than those located in the upper reaches), to determine the nutrient levels in surface water. The investigation was at the same time extended to cover other parameters relating to water quality, namely, oxygen content, turbidity, conductivity and $\mathrm{pH}$. 


\section{Material and Methods}

\subsection{The selected tanks}

The tanks were selected from the Kurunegala district which borders the dry and intermediate climate zones of Sri Lanka and is one of the main rice cultivation areas of the country. All tanks selected for sampling were minor (or small tanks) (Murray \& Little, 2000) and in relation to the cascade system, were located towards its lower reaches. None of the selected tanks were located towards the upper reaches of the cascades. Also, the selected minor tanks were surrounded largely by paddy fields with a few also being bordered by scattered rural home gardens. The surface water of a total of 50 minor irrigation tanks were sampled during the two years 2012 and 2013. The locations of these tanks are shown in Figure 1.

\subsection{Sampling water}

We assessed the water quality of the tanks through the stages pre-cultivation, cultivation and post-cultivation, with 27 tanks being sampled in the Yala season (April to August) and 23 tanks during the Maha season (September to February). On each occasion, water samples were obtained during $0700-1100$ hrs from a depth of $\sim 1.0 \mathrm{~m}$ (Wijesundara et al., 2012) using the Ruttner sampler at an approximate distance of $2 \mathrm{~m}$ or more from the edge of the water body. Care was taken to select areas that were not visibly disturbed by humans and were not covered by vegetation. Three to five samples per tank were taken in each paddy growing season giving a total of 9 15 samples per tank over the three sampling seasons.

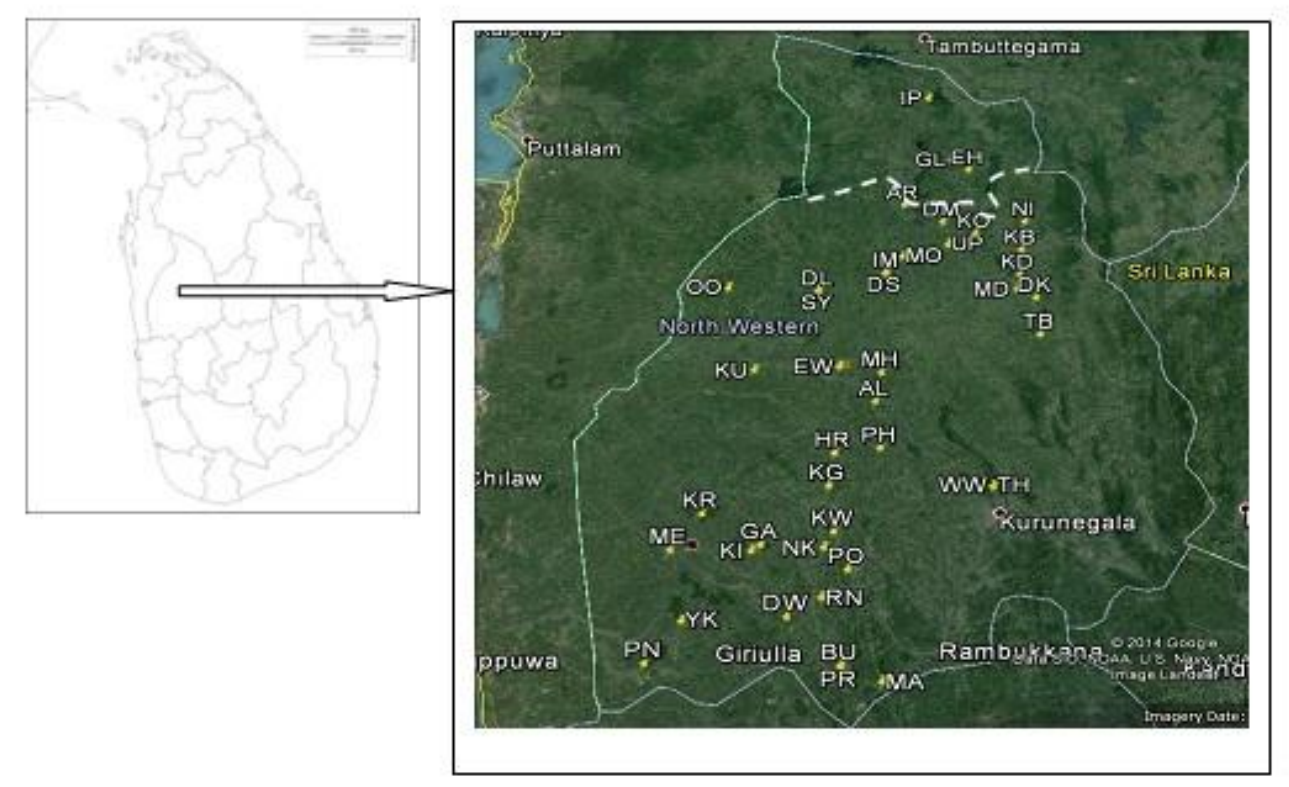

Figure1. Map of Sri Lanka and enlarged map of the Kurunegala district showing the locations of the sampled tanks. Upper section of the district demarcated by the dashed line lies in the dry zone, while the lower section falls within the intermediate zone. 
Water was collected into $350 \mathrm{ml}$ acidwashed polyethylene bottles rinsed with reservoir water prior to the addition of the sample (Yatigammana et al., 2011).

\subsection{Analyses of water}

In the laboratory the samples were analyzed for dissolved $\mathrm{NO}_{3}-\mathrm{N}$ by the cadmium reduction method and $\mathrm{PO}_{4}-\mathrm{P}$ by the vanadamolybdo phosphoric acid method (APHA, 2008), using the spectrophotometer (Thermofisher scientific 10S GENESYS, USA). To ensure accuracy of the readings obtained for $\mathrm{NO}_{3}-\mathrm{N}$ and $\mathrm{PO}_{4}-\mathrm{P}$, samples were spiked at regular intervals and readings taken. Four other parameters, dissolved oxygen, turbidity, conductivity and $\mathrm{pH}$, were also measured using the following: DO meter YSI 55, Ohio, USA; Turbidity meter WTW TURB 355T, Germany; Conductivity meter - YSI 30, USA; and pH meter HM-30v, TOA electronics Ltd, Tokyo, Japan. The instruments used for dissolved oxygen, turbidity, conductivity and $\mathrm{pH}$ were calibrated and standardized prior to use each day according to the instrument manufacturers' procedures. To ensure precision of each of the measured variables three recordings were taken from each sample (Wijesundara et al., 2012).

\subsection{Water quality index}

The water quality index value $W Q I=\sum^{\mathrm{n}} Q i$ $W i$ where $Q i$ is the sub-index for $\mathrm{i}^{\text {th }}$ water quality parameters, $W i$ is the weight (in terms of importance) associated with $i^{\text {th }}$ water quality parameter, and $n$ is the number of water quality parameters, is used to express the overall quality of a water body (Srivastava \& Kumar, 2013). This index was calculated for each minor tank for the three paddy cultivation seasons using the data for nitrate, phosphate, dissolved oxygen, turbidity, conductivity and $\mathrm{pH}$, with recommended corrections for the missing variables (Srivastava \& Kumar, 2013). Water quality values of 91-100 are rated as excellent, 71- 90 - good, 51 - 70 medium, 26 - 50 - bad and 0 - 25 - very bad (Tyagi et. al. 2013).

\section{Results}

Data in Table 1 shows that there is considerable spatial variation in $\mathrm{NO}_{3}-\mathrm{N}$ and $\mathrm{PO}_{4}-\mathrm{P}$ between the 50 individual tanks in each sampling season. Mean values for $\mathrm{NO}_{3}-\mathrm{N}$ and $\mathrm{PO}_{4}-\mathrm{P}$, calculated separately for the three sampling seasons for each tank, show that the spatial variations were statistically significant (one way ANOVA: $\mathrm{NO}_{3}-\mathrm{N}-\mathrm{F}=67.84$, $\left.\mathrm{P}<0.05 ; \mathrm{PO}_{4}-\mathrm{P}-\mathrm{F}=3.54, \mathrm{P}<0.05\right)$. The maximum level for $\mathrm{NO}_{3}-\mathrm{N}$ was $6.9 \mathrm{mg} \mathrm{l}^{-1}$ recorded from Pubbowa Wewa, whilst some tanks had values below $0.1 \mathrm{mg} \mathrm{l}^{-1}$. The maximum level for $\mathrm{PO}_{4}-\mathrm{P}$ was $8.2 \mathrm{mg}$ $\mathrm{l}^{-1}$ recorded from Ulpatha Wewa, whilst some tanks had low values of $0.1 \mathrm{mg} \mathrm{l}^{-1}$ or less. Taking all of the 50 tanks, each of which was sampled in either the yala or the maha, the study showed a marked temporal variation in $\mathrm{NO}_{3}-\mathrm{N}$ and $\mathrm{PO}_{4}-\mathrm{P}$ levels from the pre-cultivation to the post cultivation season (Table 1, Figure 2), although the differences were not statistically significant (one way ANOVA: $\mathrm{NO}_{3}-\mathrm{N}-\mathrm{F}=0.13, \mathrm{P}>0.05 ; \mathrm{PO}_{4}-\mathrm{P}-\mathrm{F}=0.001$, $\mathrm{P}>0.05)$. This is most likely due to the considerable spatial variation in the concentrations during all sampling sessions between the individual tanks (Figure 2). There was a clear shift in the proportion of tanks containing low and high nutrient loads across the sampling 
Table1. Mean ( \pm std error) of $\mathrm{NO}_{3}-\mathrm{N}$ and $\mathrm{PO}_{4}-\mathrm{P}\left(\mathrm{mg} \mathrm{l}^{-1}\right)$ in surface water of minor irrigation tanks in the Kurunegala district during three stages of the paddy growing cycle. (n=9 - 15 per $\operatorname{tank}$ )

\begin{tabular}{|c|c|c|c|c|c|c|c|}
\hline \multicolumn{2}{|r|}{ TANK } & \multicolumn{3}{|c|}{$\mathrm{NO}_{3}-\mathrm{N}\left(\mathrm{mg} \mathrm{l}^{-1}\right)$} & \multicolumn{3}{|c|}{$\mathrm{PO}_{4}-\mathrm{P}\left(\mathrm{mgl}^{-1}\right)$} \\
\hline & & PRE & CUL & POST & PRE & CUL & POST \\
\hline $\mathrm{AL}$ & Aluth wewa & $0.02 \pm 0.11$ & $1.29 \pm 0.12$ & $0.01 \pm 0.02$ & $0.56 \pm 0.01$ & $0.72 \pm 0.01$ & $0.09 \pm 0.01$ \\
\hline 00 & Oolumal wewa & $0.56 \pm 0.21$ & $5.33 \pm 0.12$ & $0.33 \pm 0.12$ & $2.40 \pm 0.01$ & $1.12 \pm 0.02$ & $1.43 \pm 0.11$ \\
\hline KD & Kadawaragedara wewa & $0.24+0.11$ & $4.38 \pm 0.01$ & $0.10 \pm 0.13$ & $1.30 \pm 0.12$ & $6.00 \pm 0.01$ & $0.98 \pm 0.15$ \\
\hline DS & Dambadeniya & $0.04 \pm 0.10$ & $0.58 \pm 0.11$ & 0.030 .11 & $0.80 \pm 0.11$ & $1.00 \pm 0.11$ & $0.34 \pm 0.27$ \\
\hline EW & Ethabewala wewa & $0.13 \pm 0.11$ & $6.05 \pm 0.01$ & $0.08 \pm 0.08$ & $1.20 \pm 0.21$ & $1.66 \pm 0.13$ & $0.65 \pm 0.19$ \\
\hline KR & Karagahagedara wewa & $0.24 \pm 0.13$ & $0.76 \pm 0.01$ & $0.10 \pm 0.01$ & $1.30 \pm 0.24$ & $1.22+0.14$ & $0.98 \pm 0.09$ \\
\hline $\mathrm{BU}$ & Balalla wewa & $0.09 \pm 0.12$ & $0.55 \pm 0.14$ & $0.07 \pm 0.00$ & $1.00 \pm 0.09$ & $0.55 \pm 0.04$ & $0.5 \pm 00.01$ \\
\hline UP & Ullala wewa & $1.32 \pm 0.11$ & $0.89 \pm 0.03$ & $1.23 \pm 0.09$ & $6.70 \pm 0.08$ & $1.52 \pm 0.11$ & $5.30 \pm 0.14$ \\
\hline EH & Ethawa wewa & $0.13 \pm 0.14$ & $0.03 \pm 0.01$ & $0.08 \pm 0.12$ & $1.10 \pm 0.00$ & $1.05 \pm 0.13$ & $0.56 \pm 0.02$ \\
\hline SY & Siyambalangamuwa wewa & $0.87 \pm 1.11$ & $0.78 \pm 0.11$ & $0.46 \pm 0.14$ & $3.60 \pm 0.03$ & $0.14 \pm 0.14$ & $2.30 \pm 0.03$ \\
\hline $\mathrm{PK}$ & Polkatu wewa & $0.74 \pm 0.10$ & $4.23 \pm 0.02$ & $0.44 \pm 0.12$ & $2.80 \pm 0.02$ & $1.00 \pm 0.02$ & $2.00 \pm 0.01$ \\
\hline GL & Galwala wewa & $0.19 \pm 0.01$ & $0.03 \pm 0.01$ & $0.09 \pm 0.22$ & $1.20 \pm 0.01$ & $0.94 \pm 0.09$ & $0.78 \pm 0.01$ \\
\hline $\mathrm{HR}$ & Horombawa wewa & $0.20 \pm 0.02$ & $4.33 \pm 0.03$ & $0.09 \pm 0.01$ & $1.20 \pm 0.11$ & $4.66 \pm 0.09$ & $0.78 \pm 0.14$ \\
\hline IM & Imbulgodayagama wewa & $0.23 \pm 0.12$ & $3.77 \pm 0.14$ & $0.09 \pm 0.11$ & $1.20 \pm 0.10$ & $1.33 \pm 0.11$ & $0.80 \pm 0.12$ \\
\hline IP & Ipalogama wewa & $1.02 \pm 0.13$ & $5.05 \pm 0.02$ & $0.09 \pm 0.11$ & $1.20 \pm 0.12$ & $5.00 \pm 0.06$ & $0.90 \pm 0.08$ \\
\hline KW & Kadadeka wewa & $0.24 \pm 0.12$ & $5.7 \pm 0.12$ & $0.09 \pm 0.09$ & $1.30 \pm 0.14$ & $4.05 \pm 0.17$ & $0.97 \pm 0.18$ \\
\hline MA & Maha wewa & $0.36 \pm 0.11$ & $4.11 \pm 0.13$ & $0.23 \pm 0.23$ & $1.50 \pm 0.14$ & $1.22+0.10$ & $1.08 \pm 0.27$ \\
\hline NW & Nebadewa wewa & $0.49 \pm 0.14$ & $1.12 \pm 0.04$ & $0.32 \pm 0.14$ & $2.20 \pm 0.02$ & $4.12 \pm 0.24$ & $1.30 \pm 0.14$ \\
\hline $\mathrm{KI}$ & Kithalawa wewa & $0.29 \pm 0.00$ & $3.03 \pm 0.05$ & $0.13 \pm 0.11$ & $1.30 \pm 0.11$ & $1.16 \pm 0.15$ & $0.98 \pm 0.02$ \\
\hline DW & Diwulgolla wewa & $0.07 \pm 0.10$ & $4.20 \pm 0.15$ & $0.06 \pm 0.01$ & $1.00 \pm 0.13$ & $6.55 \pm 0.01$ & $0.45 \pm 0.18$ \\
\hline KO & Koon wewa & $0.30 \pm 1.00$ & $4.74 \pm 0.11$ & $0.14 \pm 0.00$ & $1.30 \pm 0.14$ & $1.00 \pm 0.03$ & $0.98 \pm 0.13$ \\
\hline $\mathrm{KU}$ & Kuliyapitiya wewa & $0.32 \pm 0.01$ & $1.81 \pm 0.14$ & $0.15 \pm 0.02$ & $1.40 \pm 0.17$ & $1.16 \pm 0.15$ & $1.00 \pm 0.01$ \\
\hline KB & Kumbukulawa Maha wewa & $0.32 \pm 0.05$ & $5.53 \pm 0.01$ & $0.18 \pm 0.02$ & $1.40 \pm 0.12$ & $1.09 \pm 0.19$ & $1.00 \pm 0.13$ \\
\hline MD & Madagalla wewa & $0.33 \pm 0.02$ & $3.81 \pm 0.11$ & $0.23 \pm 0.10$ & $1.50 \pm 0.01$ & $1.38 \pm 0.11$ & $1.03 \pm 0.01$ \\
\hline RB & Rambukana wewa & $0.81 \pm 0.11$ & $1.02 \pm 0.03$ & $0.45 \pm 0.14$ & $3.30 \pm 0.09$ & $1.23 \pm 0.24$ & $2.10 \pm 0.00$ \\
\hline DM & Dematewa wewa & $0.06 \pm 0.01$ & $5.17 \pm 0.01$ & $0.03 \pm 0.11$ & $0.90 \pm 0.12$ & $2.16 \pm 0.04$ & $0.40 \pm 0.19$ \\
\hline MH & Mitiyagane wewa & $0.43+0.19$ & $4.02 \pm 0.04$ & $0.23+0.04$ & $1.80 \pm 0.09$ & $1.55 \pm 0.01$ & $1.20 \pm 0.01$ \\
\hline TB & Thimbirigahamula wewa & $0.98 \pm 0.04$ & 0.970 .11 & $0.78 \pm 0.21$ & $5.60 \pm 0.01$ & $1.04 \pm 0.00$ & $4.00 \pm 0.00$ \\
\hline $\mathrm{NK}$ & Nakkawatta wewa & $1.46 \pm 0.14$ & $3.01 \pm 0.19$ & $0.24 \pm 0.14$ & $2.10 \pm 0.00$ & $0.98 \pm 0.23$ & $1.30 \pm 0.02$ \\
\hline $\mathrm{EH}$ & Ehetu wewa & $0.09 \pm 0.02$ & $0.65 \pm 0.17$ & $0.07 \pm 0.00$ & $1.00 \pm 0.00$ & $0.66 \pm 0.13$ & $0.50 \pm 0.24$ \\
\hline NI & Nika wewa & $0.53 \pm 0.14$ & $0.54 \pm 0.11$ & $0.32 \pm 0.09$ & $2.40 \pm 0.01$ & $3.15 \pm 0.04$ & $1.30 \pm 0.06$ \\
\hline DL & Daladagama wewa & $0.03 \pm 0.11$ & $2.07 \pm 0.24$ & $0.03 \pm 0.09$ & $0.70 \pm 0.02$ & $7.55 \pm 0.01$ & $0.34 \pm 0.17$ \\
\hline $\mathrm{PH}$ & Pahala wewa & $0.57 \pm 0.11$ & $1.23 \pm 0.00$ & $0.33 \pm 0.00$ & $2.40 \pm 0.01$ & $0.89 \pm 0.11$ & $1.60 \pm 0.01$ \\
\hline PL & Palapathwala wewa & $0.61 \pm 0.10$ & $3.14 \pm 0.24$ & $0.43 \pm 0.11$ & $2.50 \pm 0.21$ & $0.75 \pm 0.02$ & $1.80 \pm 0.11$ \\
\hline ME & Meegahakiwula wewa & $0.43 \pm 0.23$ & $1.23 \pm 0.17$ & $0.23 \pm 0.34$ & $1.80 \pm 0.14$ & $1.38 \pm 0.00$ & $1.20 \pm 0.13$ \\
\hline PR & Paranagama & $0.67 \pm 0.19$ & $5.45 \pm 0.01$ & $0.43 \pm 0.13$ & $2.70 \pm 0.19$ & $1.21 \pm 0.06$ & $1.90 \pm 0.02$ \\
\hline MO & Moonamalegama wewa & $0.46 \pm 0.19$ & $2.12 \pm 0.08$ & $0.24 \pm 0.17$ & $1.90 \pm 0.08$ & $2.45 \pm 0.01$ & $1.20 \pm 0.04$ \\
\hline $\mathrm{PO}$ & Polpitiya wewa & $0.75 \pm 0.13$ & $3.65 \pm 0.12$ & $0.45+0.09$ & $2.80 \pm 0.17$ & $1.26 \pm 0.06$ & $2.10 \pm 0.00$ \\
\hline RN & Ranmuthugala w & $0.81 \pm 0.19$ & $0.56 \pm 0.01$ & $0.45 \pm 0.00$ & $3.60 \pm 0.01$ & $1.12 \pm 0.00$ & $2.30 \pm 0.09$ \\
\hline GA & Gallewa wewa & $0.17 \pm 0.19$ & $4.24 \pm 0.09$ & $0.08 \pm 0.01$ & $1.20 \pm 0.01$ & $1.38 \pm 0.00$ & $0.78 \pm 0.01$ \\
\hline $\mathrm{PN}$ & Pannala wewa & $0.65 \pm 0.11$ & $1.45 \pm 0.23$ & $0.43 \pm 0.13$ & $2.70 \pm 0.00$ & $1.04 \pm 0.00$ & $1.80 \pm 0.11$ \\
\hline AR & Arson wewa & $0.02 \pm 0.223$ & $1.32 \pm 0.21$ & $0.02 \pm 0.09$ & $0.60 \pm 0.09$ & $1.61 \pm 0.00$ & $0.13 \pm 0.12$ \\
\hline SU & Sudheeragama wewa & $0.87 \pm 0.31$ & $2.01 \pm 0.11$ & $0.49 \pm 0.00$ & $3.90 \pm 0.03$ & $0.87 \pm 0.01$ & $2.40 \pm 0.10$ \\
\hline TH & Thalakola wewa & $0.88 \pm 0.11$ & $1.31 \pm 0.12$ & $0.67 \pm 0.01$ & $4.00 \pm 0.16$ & $1.23 \pm 0.01$ & $3.60 \pm 0.03$ \\
\hline YK & Yakwila & $0.98 \pm 0.40$ & $2.34 \pm 0.12$ & $0.56 \pm 0.01$ & $4.52 \pm 0.01$ & $1.65+0.03$ & $1.78 \pm 0.01$ \\
\hline $\mathrm{TH}$ & Thiththawella wewa & $1.24 \pm 0.05$ & $0.44 \pm 0.13$ & $0.78 \pm 0.07$ & $6.40 \pm 0.11$ & $1.25 \pm 0.02$ & $4.50 \pm 0.00$ \\
\hline KN & Kongoda wewa & $0.29 \pm 0.16$ & $2.35 \pm 0.01$ & $0.13 \pm 0.01$ & $1.30 \pm 0.13$ & $1.16 \pm 0.01$ & $0.98 \pm 0.00$ \\
\hline UL & Ulpatha wewa & $1.87 \pm 0.12$ & $2.33 \pm 0.12$ & $1.98 \pm 0.01$ & $8.20 \pm 0.14$ & $1.22+0.00$ & $5.40 \pm 0.00$ \\
\hline WW & Wewagedara wewa & $0.78 \pm 0.13$ & $2.11 \pm 0.13$ & $1.09 \pm 0.01$ & $5.50 \pm 0.00$ & $2.33 \pm 0.00$ & $3.40 \pm 0.01$ \\
\hline PB & Pubbowa wewa & $0.76 \pm 0.00$ & $6.90 \pm 0.14$ & $0.45 \pm 0.15$ & $3.00 \pm 0.07$ & $0.98 \pm 0.00$ & $2.10 \pm 0.09$ \\
\hline
\end{tabular}


periods (Figure 3). In the case of $\mathrm{NO}_{3}-\mathrm{N}$, during the pre-cultivation and postcultivation stages, mean levels of 0.01 $0.99 \mathrm{mg} \mathrm{l}^{-1}$ were observed in $75 \%$ and 69 $\%$ of the tanks, respectively. During the cultivation stage, however, the situation was reversed and as many as $75 \%$ of the tanks had high nutrient loads of $1.0-5.0$ $\mathrm{mg} \mathrm{l}^{-1}$ (Figure 3). Patterns for $\mathrm{PO}_{4}-\mathrm{P}$ were different. Of the 50 tanks, the majority had mean levels of $1-5 \mathrm{mg} \mathrm{l}^{-1} \mathrm{PO}_{4}-\mathrm{P}$ during all three sampling periods (precultivation $86 \%$, cultivation $86 \%$, postcultivation $67 \%$ ) (Figure 3), a marginal decline in $\mathrm{PO}_{4}$ - $\mathrm{P}$ level occurring from the cultivation to the post- cultivation season. Taking the $\mathrm{NO}_{3}-\mathrm{N}$ levels in the tanks during the two rice cultivation seasons yala $(\mathrm{n}=27)$ and maha $(\mathrm{n}=23)$ separately (Figure 2), a mid season peak is seen to occur in both sets, with the yala peak being marginally higher than the maha peak. The pattern for $\mathrm{PO}_{4}$-P was markedly different. Here the peaks occurred during the pre-cultivation season of both yala and maha, and were less pronounced. Comparing results with set standards of the CEA (2010), the values reported here (Figure 2) show that $\mathrm{NO}_{3}-\mathrm{N}$ levels exceed $5 \mathrm{mgl}^{-1}$, which is the safety limit for aquatic fauna, only during the cultivation stage (Table 1). On the other hand, the safety level of $\mathrm{PO}_{3}-\mathrm{P}$ for aquatic life is 0.4 $\mathrm{mgl}^{-1}$. Thus, based on the recorded values, a majority of the tanks exceeded these limits throughout the sampling period (Table 1).

In the 50 sampled tanks, notable spatial variation was seen for dissolved oxygen, turbidity, conductivity and $\mathrm{pH}$, and, with the exception of conductivity, these variations were significant (one-way ANOVA: dissolved oxygen $F=6.70$, $\mathrm{P}<0.05$; turbidity $\mathrm{F}=64.71, \mathrm{P}<0.05$; conductivity $\mathrm{F}=2.91, \mathrm{P}>0.05 ; \mathrm{pH} F=$
11.88, $\mathrm{P}<0.05)$. As with nitrate and phosphate, temporal variations were observed in the levels of these four parameters from the pre-cultivation to the post-cultivation stage (Figure 4). These temporal changes were not statistically significant (one-way ANOVA : dissolved oxygen $-\mathrm{F}=0.66 \mathrm{p}>0.05 ; \mathrm{pH}$ $\mathrm{F}=0.75 \mathrm{P}>0.05$; conductivity $-\mathrm{F}=0.02$, $\mathrm{P}>0.05$; turbidity $-\mathrm{F}=1.90 \mathrm{P}>0.05$ ), most likely due to large variation in the standard error values of these parameters. Accordingly there was also a shift in the number of tanks containing low to high levels of the different parameters through its progression from the pre-cultivation to the post-cultivation stages (Figure 5).
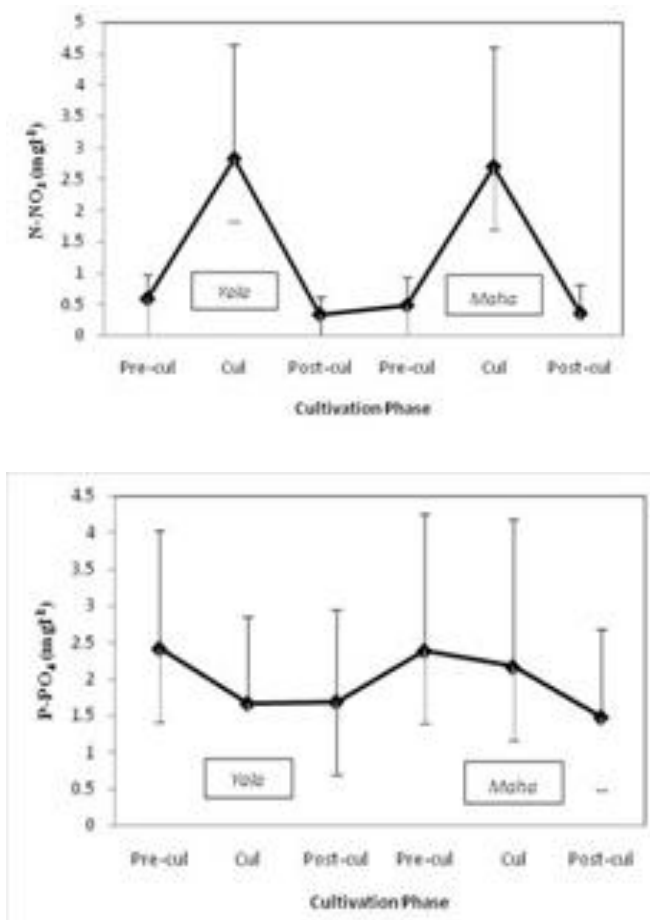

Figure 2: Fluctuation in the mean values of nitrate and phosphate in minor irrigation tanks at precultivation, cultivation and post-cultivation stages of the Yala $(\mathrm{n}=27)$ and Maha $(\mathrm{n}=23)$ seasons. CEA recommendations for aquatic life nitrate $5 \mathrm{mgl}^{-1}$ and phosphate $0.4 \mathrm{mgl}^{-1}$. Note: although mean values for nitrate are within the safety level, values in some tanks exceed this level as shown in Table 1 and Fig. 3

June 2017 

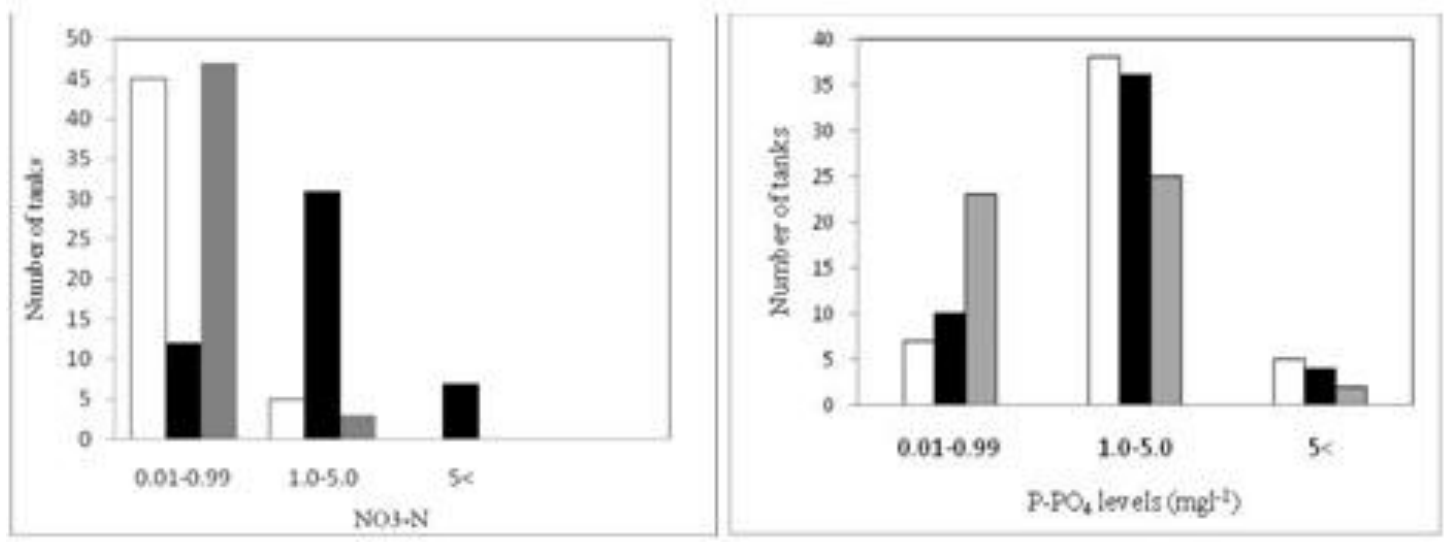

Figure 3. Number of minor tanks recording nutrient levels ranging from low $0.01-$ $\left.0.099 \mathrm{mg} \mathrm{l}^{-1}\right)$ and high (5 mg l-1 and over) in the pre-cultivation (empty bars), cultivation (black) and post-cultivation (grey) stages of the paddy cycle.
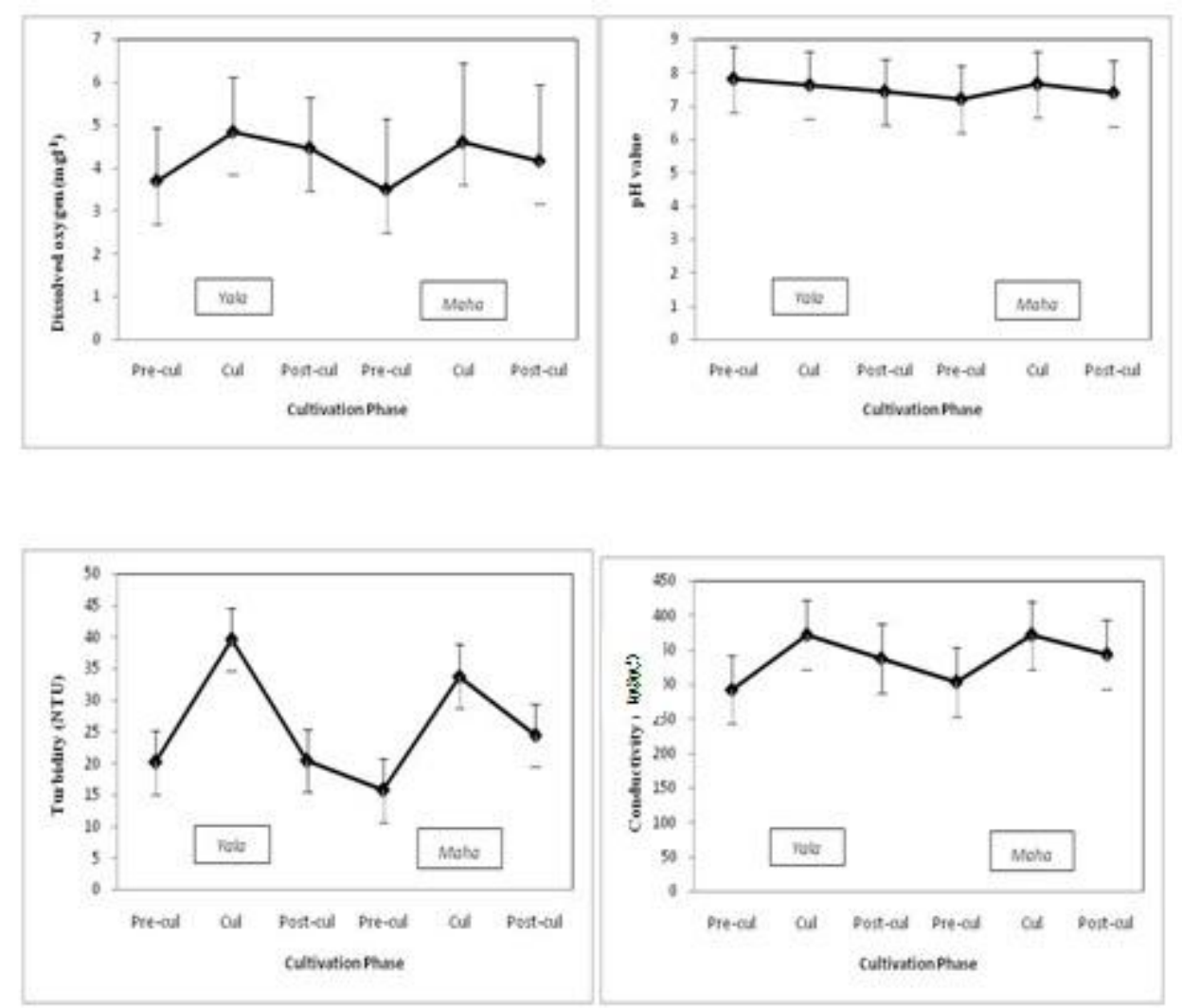

Figure 4: Fluctuation in mean levels of four water quality parameters at precultivation, cultivation and post-cultivation stages of the Yala $(\mathrm{n}=27)$ and Maha $(\mathrm{n}=23)$ seasons. CEA recommendations for aquatic life oxygen $3 \mathrm{mgl}^{-1}$ and $\mathrm{pH} 6.0$ 8.5. No values provided for conductivity $\left(\mathrm{mSm}^{-1}\right)$ and turbidity for aquatic life. 

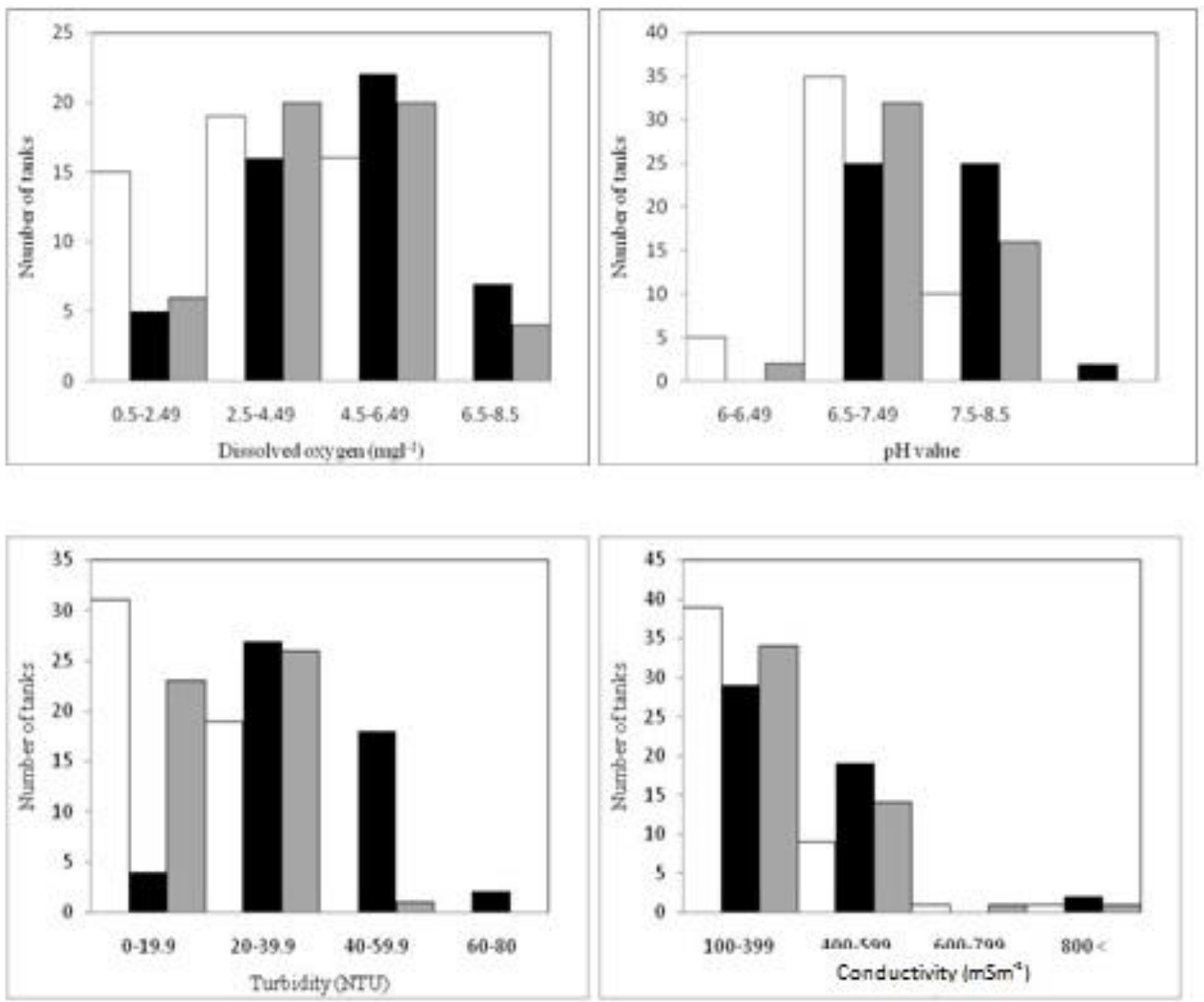

Figure 5. The number of tanks having low to high levels of dissolved oxygen, $\mathrm{pH}$, turbidity and conductivity $\left(\mathrm{mSm}^{-1}\right)$ during pre-cultivation (empty bars), cultivation (back bars) and post-cultivation (grey bars) stages of the paddy cycle.

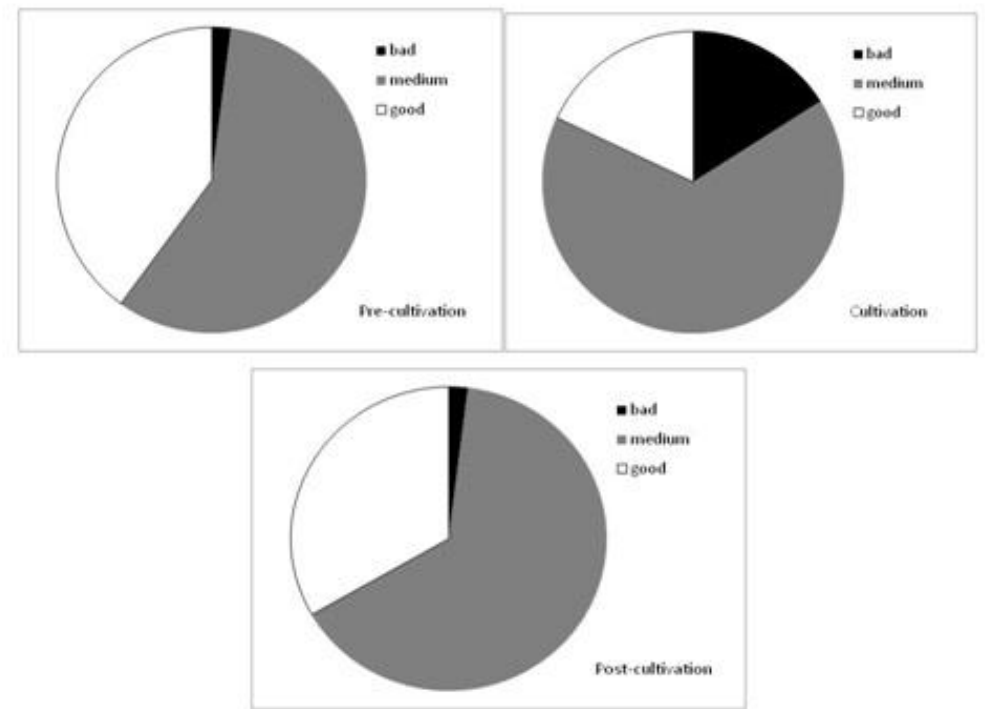

Figure 6. The proportion of good (white), medium (grey) and poor (black) quality tanks during the pre-cultivation, cultivation and post-cultivation stages of the paddy cultivation cycle based on water quality indices (WQI - by Srivastava \& Kumar, 2013). 
Oxygen levels in the individual tanks fluctuated between 0.5 - $8.5 \mathrm{mg} \mathrm{l}^{-1}$, with considerable variation between tanks. Whilst the dissolved oxygen safety limit for the sustenance of aquatic life set by the CEA is $3 \mathrm{mg} \mathrm{l}^{-1}$, it is noteworthy that about $30 \%$ of the tanks had an oxygen level of $2.5 \mathrm{mg} \mathrm{l}^{-1}$ or below during the precultivation season (Figure 5). One tank (Horombawa Wewa) recorded severe oxygen depletion $\left(<1 \mathrm{mg} \mathrm{l}^{-1}\right)$ throughout, from the pre-cultivation to the post cultivation season. Most tanks reached a peak in the oxygen level during paddy cultivation (Figure 4). The $\mathrm{pH}$ values varied little and were either neutral (7.0) or very slightly alkaline (Figure 4), with a maximum of 7.9, and are within the recommended safety levels for aquatic life. Turbidity values fluctuated from the pre-cultivation to the post-cultivation stages, with two prominent peaks during the cultivation seasons. Over $50 \%$ of the tanks had turbidity levels from 10 - 20 NTU during the pre-cultivation season, but this shifted to about $75 \%$ of the tanks having values that exceeded 30 NTU during the cultivation season. The overall levels in tanks once again dropped to 10 20 NTU during the post- cultivation period. Conductivity followed a similar pattern as turbidity, although the peaks were much less pronounced. Overall the values did not vary markedly, with a majority of the tanks having values ranging from 300 - $400 \mathrm{mSm}^{-1}$, throughout sampling (Figure 4). No values have been specified by the CEA for turbidity or conductivity. For turbidity the peaks were marginally higher in the Yala than that in the Maha. No distinct differences were observed for dissolved oxygen, $\mathrm{pH}$ and conductivity between the two paddy growing seasons Yala and Maha.
The water quality index values (WQI) indicate that during pre-cultivation $1 \%$ of the tanks had 'bad quality' water whist 55 $\%$ had 'medium quality' water and $42 \%$ had water of 'good quality'. The situation deteriorated during the cultivation stage when $15 \%$ had 'bad quality' water, $67 \%$ had 'medium quality' water and only 17 $\%$ had 'good quality' water. The situation improved markedly during the postcultivation season when the tanks had medium (64\%) or good quality (33\%) water (Figure 6).

\section{Discussion}

The sampled minor tanks in the Kurunegala district exhibited a great deal of spatial and temporal variation in the basic water quality parameters. Spatial variability is typically influenced by numerous factors such as the abundance of aquatic plants and phytoplankton, capacity and extent of the tank, extent and nature of the micro catchments, and the number and size of the inlet channels (Johnes, 1996; Piotrowicz et al. 2006), all being factors that differ considerably between the individual tanks in the study area. The overall values recorded in the present study for $\mathrm{NO}_{3}-\mathrm{N}$ (up to $6.9 \mathrm{mgl}^{-1}$ ) are consistent with values reported previously for irrigation tanks in Sri Lanka, but those for $\mathrm{PO}_{4}-\mathrm{P}$ (up to $8.2 \mathrm{mgl}^{-}$ 1) far exceed previously reported values (Young et al., 2010; Wijesundara et al., 2012). In some large tanks, however, much lower levels $\left(<1.00 \mathrm{mgl}^{-1}\right.$ ) have been recorded (Sethunge \& Manage, 2010).

The present study, though also noting spatial variations, focused primarily on investigating temporal fluctuations in water quality of the minor tanks. Temporal changes in nutrient levels in a 
water body reflect the balance between enrichment, uptake, dilution during the rainy season and concentration during the dry season, as well as the extent of drainage of tank water for irrigation purposes. Nutrient loads in tanks would increase considerably when fertilizerladen water stocked in paddy fields is discharged through outlet canals or streams and enter the irrigation tanks at lower elevations in the cascade during the post-reproductive phase of the crop, or when surface run off enters the water body during the rainy season. The cascade system is such that the rice paddies and tanks occur as a series and a given tank may irrigate paddies below whilst at the same time receiving flow and runoff from paddies above it. The bell shaped trend observed for $\mathrm{NO}_{3}-\mathrm{N}$ for both yala and maha could be explained as being due to the $\mathrm{NO}_{3}-\mathrm{N}$ reducing during pre- and post- cultivation periods, and rising to a peak during cultivation, a fluctuation pattern that has also been observed by Wijesundara et al., 2012, in a sample of six tanks in the same district. Nevertheless, the pattern of temporal fluctuation of $\mathrm{PO}_{4}-\mathrm{P}$ in the 50 sampled tanks was strikingly different from that of $\mathrm{NO}_{3}-\mathrm{N}$, from what has been reported in previous studies where similar patterns of fluctuation were reported for both $\mathrm{PO}_{4}$ $\mathrm{P}$ and $\mathrm{NO}_{3}-\mathrm{N}$. The difference reported here, where 50 tanks were sampled, could be attributed to the overall influence of the differential rates of adsorption of the two nutrients to soil and organic matter. It is reported that $\mathrm{PO}_{4}-\mathrm{P}$, in comparison to $\mathrm{NO}_{3} \mathrm{~N}$, is more readily adsorbed to soil surfaces and organic matter, causing a part of the $\mathrm{PO}_{4}$-P emanating from paddy fields to be retained in the fields and intervening areas without entering irrigation tanks (Rast \& Lee, 1983; Johnes 1996). Increase in $\mathrm{PO}_{4}-\mathrm{P}$ in the tanks will occur subsequently when heavy rains bring in the adsorbed ions, mainly during the start of the maha, although some measure of dilution would also occur. These processes will result in a less pronounced variation of $\mathrm{PO}_{4}-\mathrm{P}$ in the tanks across a paddy growing season. In contrast, a large proportion of $\mathrm{NO}_{3}-\mathrm{N}$ is directly washed into the tanks with the release of water from paddy fields during post-reproductive phase in the latter half of the cultivation seasons causing pronounced fluctuations between the cultivation and non-cultivation periods. Another factor that affects, to varying degrees, the bioavailability of the two nutrients is re-suspension or bioturbation. It is reported that bottom grazers such as carps (Cyprinus carpio) and tank cleaners (Ptryeoplichthys multiradiatus), found in abundance in the local tanks, disturb the sediment releasing phosphates in autochthonous inputs into the water column (Hille et al., 2005; Mishra et al., 1995) contributing to the disparity in bioavailability of $\mathrm{N}$ and $\mathrm{P}$ at a given time.

The need for monitoring water quality is to determine the suitability of the water for the different purposes for which it is used. For $\mathrm{NO}_{3}-\mathrm{N}$, water containing up to 5 $\mathrm{mgl}^{-1}$ is considered safe for fish and other aquatic life, while for $\mathrm{PO}_{4}-\mathrm{P}$ the values are $0.7 \mathrm{mg} \mathrm{l}^{-1}$ and $0.4 \mathrm{mg} \mathrm{l}^{-1}$ respectively (CEA 2010). The present study notes that while only around $5 \%$ of the tanks have $\mathrm{NO}_{3}-\mathrm{N}$ concentrations exceeding the limit and only during cultivation, $98 \%$ of the tanks exceeded the limit for $\mathrm{PO}^{4}-\mathrm{P}$ during some stage of sampling. For $\mathrm{NO}_{3}-\mathrm{N}$, it should be noted that long term exposure to levels even as low as $3 \mathrm{mg}^{-1}$ have been shown to be toxic to fish and shellfish (Camargo et al., 2005), suggesting that the levels recorded in many tanks, although 
within locally recommended safety limits during much of the year, may be hazardous. Furthermore, particularly based on $\mathrm{PO}_{4}$-P levels, $100 \%$ of the tanks become eutrophic during paddy cultivation (see limits set by Cunha et al., 2012), a condition that has also been noted for several other lakes and reservoirs in Sri Lanka (e.g. Kurunegala tank: Peiris \& Miguntanna, 2012; Kotmale reservoir: Piyasiri 1995).

At a given time, the dissolved oxygen values in a standing water body would reflect the balance between the production of oxygen by photosynthetic organisms and usage of oxygen for respiration by all forms of aquatic life. Overall, the highest levels were recorded during cultivation, most likely due to the increased growth of photosynthetic organisms resulting from nutrient enrichment at this time. Although dissolved oxygen in tanks did not appear to reach hypoxic levels, some tanks temporarily recorded low levels of below $3 \mathrm{mgl}^{1}$, which may pose a threat to aquatic fish. The overall trends in $\mathrm{pH}$, varying between neutral and very slightly alkaline, follow the trends of $\mathrm{pH}$ fluctuations generally seen in paddy field water (Boyd, 1979). With respect to turbidity, as expected, the incoming sediment would have caused the observed increase in turbidity during cultivation. No safety limits have been set by the CEA for aquatic life but studies elsewhere have revealed that adverse impacts on fish are evident only at levels of 30 NTU and above (Berg 1982). Hence the values recorded here are no cause for immediate concern. No substantial changes in conductivity were evident through the sampling stages although the marginal peaks could be explained by the inflow of sediment during paddy cultivation. While these minor irrigation tanks may vary somewhat in depth, water quality as revealed by the index values which take into account all of the tested parameters, including nutrients, indicate that paddy cultivation contributes to the deterioration of the water quality in these tanks during the cultivation season.

In the past, the cascade system of tanks would have been commendable because of its capacity to buffer effects of anthropogenic activities and to provide for the optimal use of the available water resources. Modern agricultural practices, however, are a significant departure from the ancient agro-ecological systems; this includes a shift from organic farming to chemical fertilizers, coupled with increased rates of application, and a reduction in habitat heterogeneity in the catchment areas of the tanks. The latter refers to the loss of forests and of riparian vegetation along inlet channels and in intervening areas between paddy fields and tanks; their presence would have served to absorb much of the nutrients, lowering the amounts entering irrigation tanks.

Since the minor tanks are used by people for their daily needs, and also more importantly for harvesting fish, the findings of the present study may have important implications for the inland fishery industry. Based on the values reported here, particularly for nutrients, a large majority of the minor tanks may not at present provide optimal conditions for the rearing of fish and shellfish throughout the year. Therefore suitable mitigatory measures should be put in place, particularly because special efforts are being made to boost the country's inland fishery industry (NAQDA, 2015). What can be done to reduce nutrient 
enrichment? Any practice that would reduce soil and particulate matter entering irrigation tanks will help. Some of the less costly and practical measures that could be adopted is the establishment of green filter strips and sedimentation basins (Schmitt et al., 1999) and the use of polyacrylamide (PAM) and straw mulch (Faucette et al., 2007) in intervening areas between the paddy fields and the recipient irrigation tanks. These inexpensive and basic measures coupled with the more prudent use of fertilizers will nourish cultivated lands while concurrently increasing the income generating capacity of Sri Lanka's irrigation tanks.

\section{Conclusion}

In conclusion the present study demonstrates marked variations in nutrient levels in minor tanks across three stages of paddy cultivation, namely pre-cultivation, cultivation and post cultivation periods, in the Kurunegala District. There was considerable variation in water quality across the three seasons (temporal) and between the tanks (spatial) under consideration. Overall, however, water quality is seen to deteriorate during the paddy cultivation season indicating the possibility of the tanks becoming eutrophic, and hence may not provide optimal conditions for rearing of fish and shellfish unless suitable mitigation measures are adopted.

\section{Acknowledgement}

Financial assistance from the National Research Council Sri Lanka (Grant No. 12053) is acknowledged.

\section{References}

APHA (2008). Standard methods for the examination of water and waste water, $18^{\text {th }}$ edition, American Public Health Association, Washington, D. C.

Berg, L. (1982). The effect of exposure of short-term pulses of suspended sediment on the behavior of juvenile salmonids. Proceedings of the Carnation Creek workshop: a ten year review, Nanaimo, BC. pp. 177-196.

Boyd C. E. (1979). Water Quality in warm water fish ponds. Auburn University, Alabama, pp.359.

Camargo J.A., Alonso A. \& Salamanca A. (2005). Nitrate toxicity to aquatic animals: a review with new data for freshwater invertebrates. Chemosphere 58: 1255-1267.

CEA (2010). Proposed water quality standards. Central Environment Authority, Colombo.

Cunha D. G., Ogura A.P. \& Calijuri M.D. (2012) Nutrient reference concentrations and trophic state boundaries in subtropical reservoirs. Water Science and Technology 65(8):1461-1467.

Ekanayake H.K.J. (2006). Impact of fertilizer subsidy in paddy cultivation in Sri Lanka. Staff Studies No. 36, Central Bank of Sri Lanka, pp. 73-101.

Faucette L.B., Governo J., Jordan C. F., Lockaby B.J., Carino, H.F. \& Governo R. (2007). Erosion control and storm water quality from straw with PAM, mulch, and compost blankets of varying particle sizes. Journal of Soil and Water Conservation 62(6):404-413. 
NAQDA (National Aquaculture

Development Authority) (2015). At

http://www.naqda.gov.lk/stocking fish.ph

p Accessed: July 2015.

Hille S., Nausch G. \& Leipe T. (2005).

Sedimentary deposition and reflux of phosphorus (P) in the Eastern Gotland Basin and their coupling with $\mathrm{P}$ concentrations in the water column. Oceanologia 47: 663-679.

Johnes P. J. (1996). Evaluation and management of the impact of land use change on the nitrogen and phosphorus load delivered to surface waters: the export coefficient modeling approach. Journal of Hydrology 183: 323349.

Madduma Bandara C.M. (1985). Catchment ecosystems and village tank cascades in the dry zone of Sri Lanka: a time-tested system of land and water management. In: J. Lundquist \& M. Falkenark (eds.) Strategies for river basin management, pp. 99-113. J Reidel Publishing Company.

Mishra P. C., Behera N., Senapati B. K. \& Guru B. C. (1995). Advances in ecology and environmental sciences. Ashish Publications, New Delhi.

Murray, F.J. and Little, D.C. (2000). The Nature of Small-Scale Farmer managed Irrigation Systems in North Western Province Sri Lanka and Potential for Aquaculture. Working Paper SL1.3.

Nguyen-Khoa S. \& Lorenzen K. (2005). Impacts of irrigation on fisheries in rain fed rice farming landscapes. Journal of Applied Ecology 42(5): 892-900.

Peiris A. T. A. \& Miguntanna, N. P. (2012). Analysis of nutrients in Kurunegala Lake,
Sri Lanka. 2012 SAITM Research Symposium on Engineering Advancements (RSEA), 72-74.

Piotrowicz R., Kraska M., Klimaszyk P., Szyper H. \& Joniak T. (2006). Vegetation richness and nutrient levels in 16 lakes of Drawieński National Park, Northern Poland. Poland Journal of Environmental Studies, 15: 467-478.

Piyasiri S. (1995). Eutrophication and algae bloom problem in Kotmale Reservoir, Sri Lanka. Polish Journal of Environment Studies 15 (3): 467-478.

Rast, W. \& Fred Lee G. (1983). Nutrient loading estimates for lakes. Journal of Environmental Engineering 109: 502-517.

Sakthivadivel R., Fernando N. \& Brewer J.D. (1997). Rehabilitation planning for small tanks in cascades: a methodology based on rapid assessment. Research Report 13 of the International Irrigation Management Institute, Colombo. pp. 1-40.

Schmitt T. J., Dosskey M. G. \& Hoagland K. D. (1999). Filter strip performance and processes for different vegetation, widths, and contaminants. Journal of Environment Quality 28(5): 1479-1489.

Sethunge S. \& Manage P.M. (2010). Nuisance algae in water supply projects in Sri Lanka. International Conference on Sustainable Built Environment (ICSBE2010), Kandy, pp. 62-70.

Shinogi Y. (2001). Optimal water management of tank cascade system. Proceedings of the International commission on Irrigation and Drainage 1st Asian Regional Conference, pp.1-8. 
Silva E.I.L. (2004). Water quality in Sri Lanka - status and trends. Asian J. of Water, Environ. and pollution 1: 9-12.

Siriweera, W.I. 2002. History of Sri Lanka from earliest times up to the sixteenth century. Dayawansa Jayakody \& Company, Colombo, Sri Lanka. Srivastava G. \& Kumar P. (2013). Water quality index with missing parameters. International Journal of Research in Engineering and Technology 2 (4): 609 - 614.

Thakur D. P. \& Kwei L. (2003). Water quality and nutrient budget in closed shrimp (Penaeus monodon) culture systems. Aquacultural Engineering 27: $159-176$.

Turner R. E. \& Rabelais N. N. (2004). Suspended sediment, C, N, P and Si yields from Mississippi river basin. Hydrobiology 511: 78-89.

Tyagi, S., Sharma, B., Singh, P. \& Dobhal, R. (2013). Water Quality Assessment in Terms of Water Quality Index, American Journal of Water Resources, 1(3): 34-38.

Wijesundara W.M.G.D., Nandasena K.A. \& Jayakody A.N. (2012). Temporal variation of nitrate and phosphate in selected six small tanks of the dry zone in Sri Lanka. Tropical Agricultural Research 23 (3): 277 $-282$.

Yatigammana S.K., Illeperuma O.A. \& Perera M.B.U. (2011). Water pollution due to a harmful algal bloom: a preliminary study from two drinking water reservoirs in Kandy, Sri Lanka. Journal of National Science Foundation 39(1): 91-94.

Young S.M., Pitawala, A. \& Gunathilaka J. (2010). Fate of phosphate and nitrate in waters of an intensive agricultural area in the dry zone of Sri Lanka. Paddy water Environment. 8:71-79. 